\title{
Karakteristik Sedimentologi dan Geokimia Endapan Tsunami di Teluk Busong, Pulau Simeulue
}

\author{
Yani Kusumastuti ${ }^{1 *}$, Jenian Marin ${ }^{1}$, Purna Sulastya Putra ${ }^{2}$, Anis Kurniasih ${ }^{1}$, \\ Reddy Setyawan ${ }^{1}$, Septriono Hari Nugroho ${ }^{2}$, Eko Yulianto ${ }^{2}$ \\ ${ }^{1}$ Departemen Teknik Geologi, Fakultas Teknik, Universitas Diponegoro, \\ Jl. Prof. Soedarto, SH, Tembalang, Semarang 50275 \\ ${ }^{2}$ Pusat Penelitian Geoteknologi, LIPI, Kompleks LIPI, Jalan Sangkuriang Bandung 40135
}

\begin{abstract}
Abstrak
Sejarah tsunami modern di Pulau Simeulue tercatat telah terjadi tahun 1861, 1907, 2004 dan 2005. Teluk Busong yang terletak di pesisir barat Pulau Simeulue menjadi salah satu wilayah terdampak. Penelitian bertujuan mengidentifikasi dan mengetahui karakteristik endapan tsunami tersebut di Teluk Busong. Metode yang digunakan adalah analisis granulometri, paleontologi, analisis loss on ignition, geokimia XRF, dan FTIR pada sampel inti sedimen. Endapan tsunami pada daerah penelitian memiliki sortasi buruk dengan ukuran butir pasir sedang - kasar yang terdistribusi bimodal. Analisis LOI menunjukkan bahwa endapan tsunami memiliki kandungan material organik dan karbonat yang tinggi, menunjukkan pengaruh darat dan laut. Pengaruh laut ditunjukkan kandungan material karbonat yang signifikan, terkonfirmasi dari keberadaan cangkang foraminifera. Secara geokimia, terdapat anomali kelimpahan unsur pada endapan tsunami dibanding dengan endapan nontsunami. Unsur kimia $\mathrm{Zr}$, $\mathrm{Sr}$, $\mathrm{Fe}, \mathrm{Ti}, \mathrm{K}, \mathrm{Cr}$, dan $\mathrm{Rb}$ menunjukkan anomali pada endapan tsunami yaitu cenderung naik, terutama $\mathrm{Sr}$ yang menjadi penciri pengaruh laut. Berdasarkan analisis FTIR, ditemukan mineral kuarsa, kalsit, feldspar, aragonit, monmorilonit, paligorskit, dan magnetit pada endapan tsunami yang menunjukkan asosiasi mineral asal darat dan laut.
\end{abstract}

Kata kunci: Endapan tsunami; geokimia; Pulau Simeulue; sedimen; tsunami.

\begin{abstract}
The history of modern tsunamis on Simeulue Island was recorded in 1861, 1907, 2004 and 2005. Busong Bay which is located on the west coast of Simeulue Island is one of the affected areas. The study aims to identify and determine the characteristics of the tsunami deposit in Busong Bay. The methods used are granulometric analysis, paleontology, loss on ignition analysis, XRF geochemistry, and FTIR on core sediment samples. Tsunami deposits in the study area are poorly sorted with medium-fine sand size that are bimodally distributed. LOI analysis shows that tsunami deposits have high carbonate and organic content, that means it originated from both land and sea. The effect of the sea is shown to be a significant carbonate material content, which is confirmed by the presence of the foraminifera shell. Geochemically, there is an anomaly in the abundance of elements in tsunami deposits compared to nontsunami deposits. The chemical elements $\mathrm{Zr}, \mathrm{Sr}, \mathrm{Fe}, \mathrm{Ti}, \mathrm{K}, \mathrm{Cr}$, and $\mathrm{Rb}$ show anomalies in tsunami sediments that tend to be higher, especially $\mathrm{Sr}$ which is an indicator of sea influence. Based on FTIR analysis it was found that the minerals of quartz, calcite, feldspar, aragonite, montmorillonite, palygorskite, and magnetite in tsunami sediments showed the association of minerals from land and sea.
\end{abstract}

Keywords: tsunami deposit; geochemistry Simeulue Island; sediment; tsunami.

\section{PENDAHULUAN}

Zona subduksi Pulau Sumatra merupakan daerah dengan potensi kegempaan aktif. Gempabumi dengan kekuatan lebih dari 9.0 Skala Richter terjadi pada 26 Desember 2004, mengakibatkan gelombang tsunami besar yang menyapu sebagian besar daratan sepanjang pantai barat Sumatra. Pusat gempabumi berada di lantai samudera dekat dengan Pulau Simeulue, 160 km sebelah baratlaut dari pantai Sumatera. Kejadian bencana geologi tersebut yang akan selalu berulang dengan intensitas yang berbeda-beda.

*) Korespondensi : yanikusuma42@gmail.com 
Pemahaman terhadap karakter dan intensitas tsunami di suatu daerah tidak dapat dipahami sepenuhnya hanya dari satu kejadian saja (Goff dkk., 2004).

Penelitian mengenai tsunami yang berasosiasi dengan gempabumi di Pulau Simeulue oleh Whitlow (2008) membahas tentang karakterisasi endapan tsunami meliputi tekstur, struktur, dan hubungan stratigafinya. Penelitian tersebut menemukan adanya endapan tsunami dari paling tidak dua kejadian di masa lalu, yaitu 2004 dan 1861. Endapan ini dicirikan dengan struktur ripup clast, flame, dan bidang erosional pada endapan berukuran pasir yang kontras ukurannya dengan endapan lumpur di darat. Analisis stratigrafi di Inor, Teluk Busong, dan Teluk Langi menunjukkan jangkauan tsunami tahun 1861 hingga $350 \mathrm{~m}$ ke arah daratan. Endapan pada Teluk Busong juga menunjukkan jangkauan tsunami tahun 2004 hingga $60 \mathrm{~m}$ ke arah daratan.

Untuk memahami fenomena tsunami, berbagai indikator digunakan oleh para peneliti geologi; terutama yang paling banyak digunakan adalah karakteristik morfologi, sedimentologi, stratigrafi, paleontologi. Penelitian yang menggunakan indikator geokimia baru meningkat sejak 2004, dan merupakan parameter yang kuat dan sensitif terhadap dinamika yang terjadi pada peristiwa tsunami (Chague-Goff dkk., 2012). Indikator geokimia sangat diandalkan ketika berhadapan pada kejadian tsunami di daerah yang minim mikrofosil. Penerapan studi geokimia anorganik meliputi analisis mineral berat dan unsur kimia tertentu dapat digunakan untuk identifikasi endapan tsunami dan proses sedimentasi yang membentuknya.

Penelitian ini mengambil lokasi di Teluk Busong, pantai barat Pulau Simeulue yang berhadapan langsung dengan Samudra Hindia (Gambar 1). Untuk dapat mengkarakterisasi endapan tsunami dengan lebih baik, dilakukan analisis granulometri, paleontologi, loss on ignition (LOI), x-ray fluorescence (XRF), dan Fourier Transform Infrared (FTIR). Pemahaman mengenai karakteristik tsunami diharapkan dapat menjadi referensi dan masukan bagi pemerintah untuk membuat kebijakan terkait bencana tsunami.

\section{METODOLOGI}

Lokasi pengamatan dan pengambilan sampel ditentukan berdasarkan morfologi dataran yang terlindung dari arus pantai normal, dengan jarak $200-300 \mathrm{~m}$ dari garis pantai. Sampel berupa inti sedimen diambil dengan pipa PVC yang ditekan hingga kedalaman tertentu, menghasilkan sedimen tak terganggu yang mempertahankan kondisi aslinya. Selanjutnya di laboratorium, analisis dilakukan tiap $0,5 \mathrm{~cm}$ atau $1 \mathrm{~cm}$ sampel mencakup seluruh ketebalan inti sedimen yang dihasilkan.

\section{Granulometri}

Secara umum, sampel yang dihasilkan berukuran lebih kecil dari pasir. Distribusi ukuran butir diketahui dengan menggunakan alat difraksi laser Mastersizer 2000. Data diolah menggunakan Gradistat (Blott dan Pye, 2001) meliputi parameter mean, sortasi, skewness, dan kurtosis.

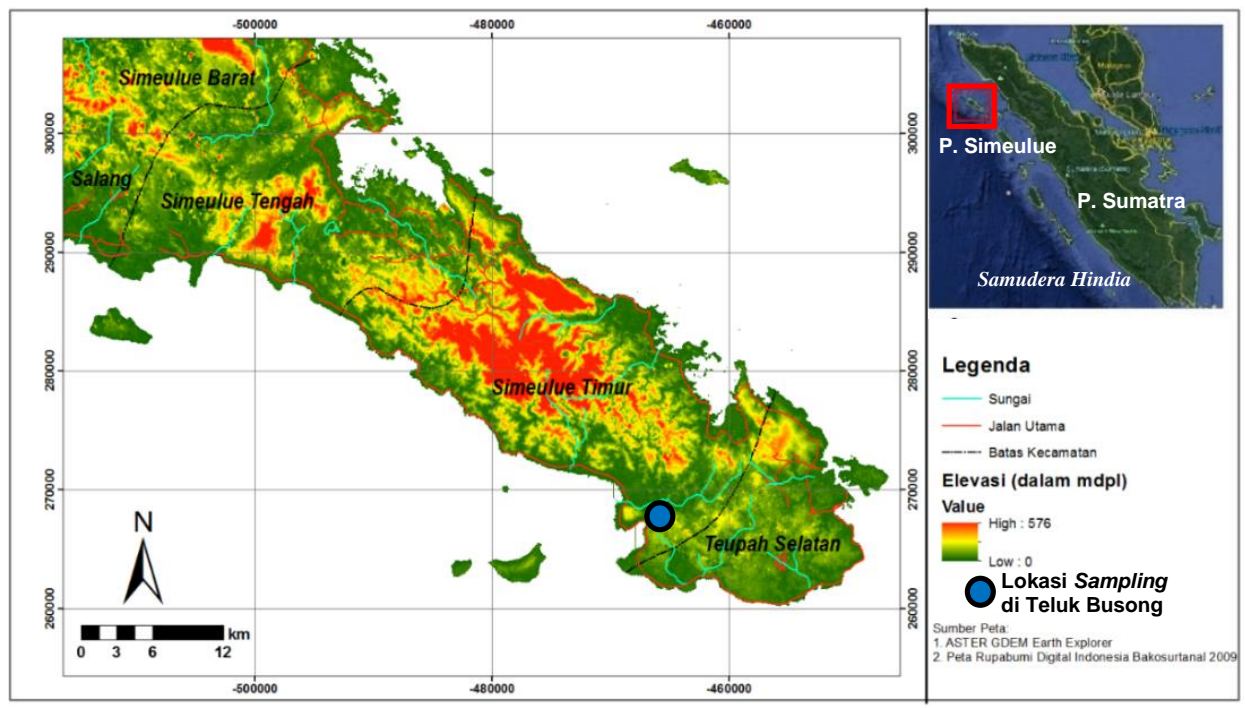

Gambar 1. Lokasi penelitian di pesisir barat Pulau Simeulue 
Analisis Paleontologi

Analisis dilakukan untuk mengetahui keberadaan cangkang foraminifera, sampel yang telah dipreparasi diamati di bawah mikroskop binokuler. Identifikasi spesies foraminifera menjadi petunjuk pengaruh laut pada endapan tsunami.

Pengamatan, determinasi dan perhitungan foraminifera penyusun sampel penelitian dilakukan pada perwakilan 1 sampel setiap lapisan yang berbeda pada lapisan non kandidat dan 4 sampel pada lapisan kandidat tsunami. Total banyaknya sampel yang dianalisis menggunakan metode ini sebanyak 10 sampel masing-masing 1 gr

\section{Loss on Ignition (LOI)}

Analisis ini bertujuan untuk mengetahui komponen organik/karbon dan karbonat pada sedimen, yang menunjukkan pengaruh atau asal material apakah dari darat atau laut. Komponen material organik dan karbonat dapat diketahui dengan pembakaran bertingkat dalam waktu tertentu. Berat sampel yang hilang dihitung secara gravimetri. Berat yang hilang pada suhu $550^{\circ} \mathrm{C}$ merupakan jumlah material organik, dan berat yang hilang pada suhu $1050^{\circ} \mathrm{C}$ merupakan jumlah material karbonat.

\section{X-Ray Fluorescence (XRF)}

Analisis ini dilakukan untuk mengetahui kandungan unsur kimia pada sampel sedimen. Alat yang digunakan adalah XRF Analyzer yang mampu merekam unsur kimia utama maupun unsur jejak hingga batas deteksi yang rendah.

\section{Fourier Transform Infrared (FTIR)}

Metode ini digunakan untuk mengidentifikasi mineral pada sampel sedimen secara kualitatif. Alat yang digunakan adalah spektrofotometer IRTracer-100. Sinar infra merah ditembakkan pada sampel, yang mana tiap jenis mineral akan menyerap sinar tersebut pada intensitas yang berbeda-beda.

\section{HASIL}

\section{Deskripsi Megaskopis Intibor}

Pengambilan intibor dilakukan pada dataran berjarak $250 \mathrm{~m}$ dari pantai. Secara geomorfologi, dataran berada di atas daerah pasang surut dengan vegetasi semak belukar dan mangrove. Pada kondisi normal, sedimentasi berasal dari tinggian dan aliran sungai di daerah sekitar.
Sampel pada lokasi ini diberi kode SIM 3B dengan kedalaman $0-60 \mathrm{~cm}$. Sedimen pada lokasi ini menunjukkan kenampakan ukuran butir pasir lanauan - pasir kasar, terdiri dari enam lapisan yang dapat dibedakan secara megaskopis (Gambar 2.). Sampel sedimen menunjukkan keterdapatan akar tumbuhan serta fragmen koral dan cangkang organisme.

\section{Analisis Granulometri}

Analisis dilakukan pada setiap $1 \mathrm{~cm}$ sampel untuk sedimen berjenis pasir atau yang lebih halus. Hasil analisis granulometri sampel SIM 3B dibagi atas 6 satuan lapisan dari tua ke muda (Gambar 3.) sebagai berikut:

1. Kedalaman $50-60 \mathrm{~cm}$ : pasir halus lanauan sortasi buruk (mean 2,438 $\phi$ ), poorly sorted $(1,197 \phi)$, fine skewed $(0,173 \phi)$, very leptokurtic (1,491 $\phi)$. Grafik unimodal menunjukkan ukuran butir relatif seragam.

2. Kedalaman $30-50 \mathrm{~cm}$ : pasir halus lanauan sortasi sedang (mean 2,330 $\phi-2,952 \phi$ ), moderately sorted - well sorted $(0,674 \phi-$ 1,301 $\phi)$, near symmetrical - fine skewed ( $0,096 \phi-0,475 \phi)$, mesokurtic, leptokurtic, dan very leptokurtic $(1,102 \phi-1,834 \phi)$. Grafik unimodal menunjukkan ukuran butir relatif seragam.

3. Kedalaman $20-30 \mathrm{~cm}$ : pasir halus lanauan sortasi buruk (mean 2,468 $\phi$ - 2,817 $\phi$ ), moderately - poorly sorted $(0,986 \phi-1,358$ $\phi)$, very fine skewed $(0,301 \phi-0.410 \phi)$, very leptokurtic $(1,686 \phi-1,888 \phi)$. Grafik unimodal menunjukkan lapisan tersusun dari satu ukuran butir saja.

4. Kedalaman $8-20 \mathrm{~cm}$ : pasir sangat halus lanauan sortasi buruk (mean 2,725 $\phi-3,322$ $\phi)$, poorly sorted $(1,129 \phi-1,477 \phi)$, very fine skewed ( $1,118 \phi-1,311 \phi)$, leptokurtic dan very leptokurtic $(1,045 \phi-1,675 \phi)$. Grafik diagram (phi) lapisan termasuk unimodal dan bimodal. Hal tersebut menunjukkan bahwa lapisan tidak hanya tersusun atas satu ukuran butir saja (Folk dan Ward, 1957).

5. Kedalaman $3-9 \mathrm{~cm}$ : pasir halus lanauan sortasi buruk kandidat tsunami (mean 1,295 $\phi$ sampai 3,299 $\phi)$, poorly sorted ( 1,098 $\phi$ $1,788 \phi)$, symmetrical, fine skewed dan very fine skewed $(0,030 \phi-0,364 \phi)$, mesocurtic, leptokurtic dan very leptokurtic $(0,575 \phi-$ $1,367 \phi)$. Grafik memiliki mode unimodal dan bimodal. 
6. Kedalaman $0-3 \mathrm{~cm}$ : pasir sangat halus lanauan sortasi buruk (mean 3,343 $\phi-3,480$ $\phi)$, poorly sorted $(1,426 \phi-1,427 \phi)$, symmetrical dan very fine skewed ( 0,096-
1,107 $\phi)$, mesokurtic $(1,074 \phi-1,099 \phi)$. Grafik memiliki mode unimodal.

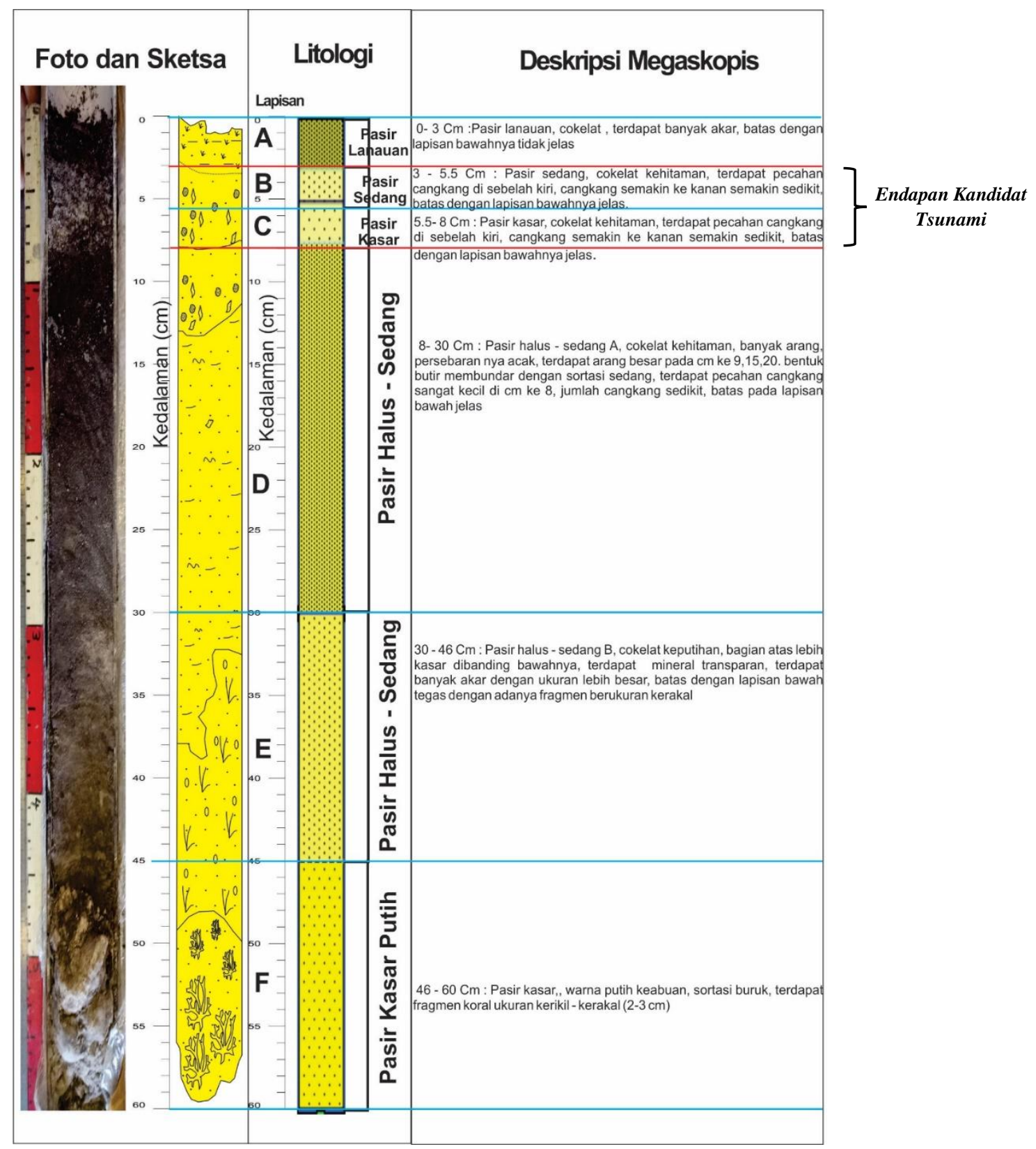

Gambar 2. Pemerian litologi sedimen secara megaskopis 


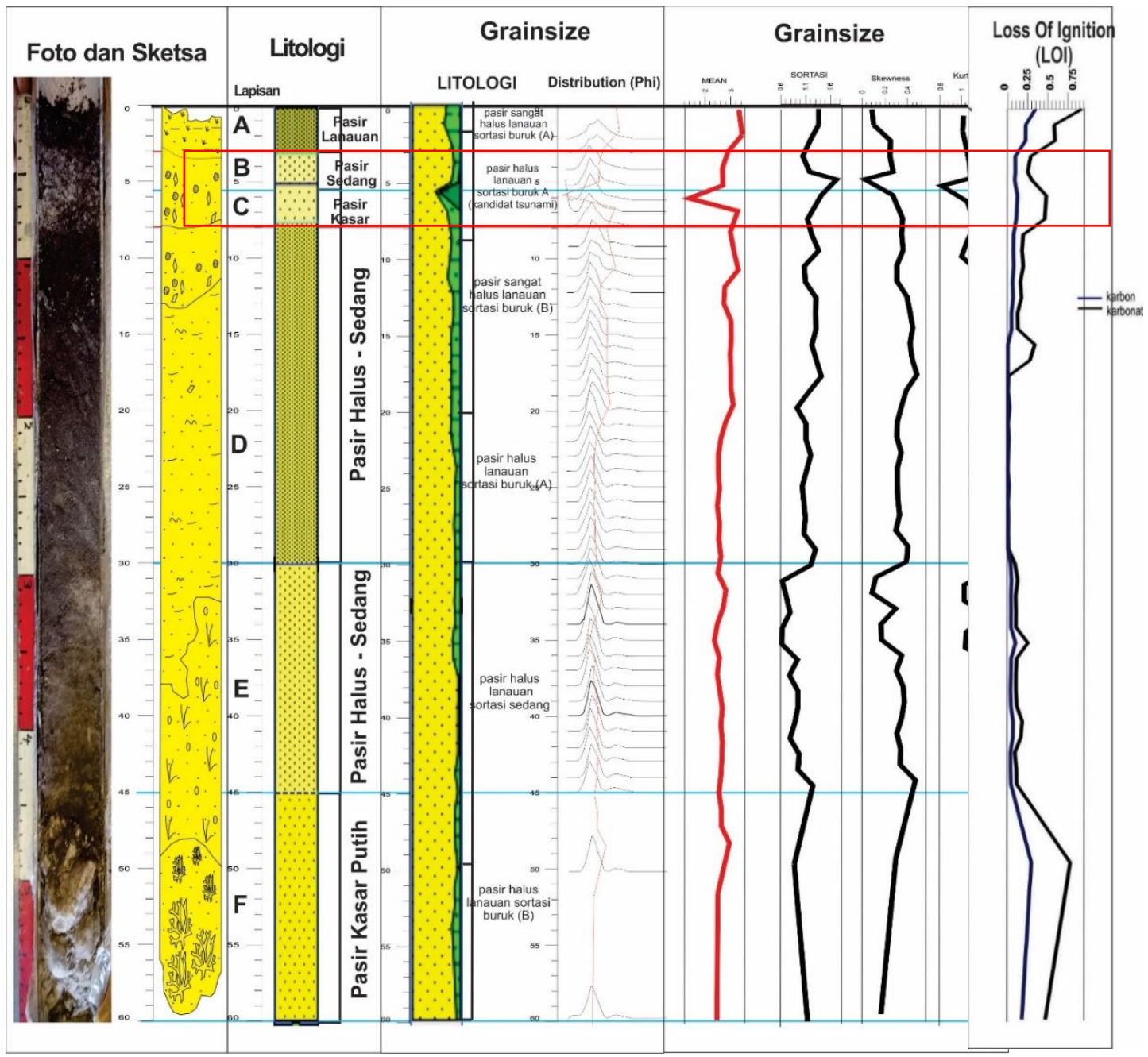

Gambar 3. Hasil analisis ukuran butir dan LoI SIM 3B

\section{Analisis LoI}

Lapisan terbawah (kedalaman $50-60 \mathrm{~cm}$ ) memiliki material organik $6,7 \%$ dan material karbonat $18 \%$. Selanjutnya, pada kedalaman $8-$ $50 \mathrm{~cm}$, kedua komponen mengalami penurunan yaitu material organik maksimal 2,9\% dan material karbonat maksimal 10,7\%. Selanjutnya terjadi kenaikan pada lapisan di atasnya (3 - 9 $\mathrm{cm}$ ), di mana kandungan organik/karbon naik hingga $8 \%$ dan kandungan karbonat 26,5\%, mengecil kembali ke atas sebelum naik lagi di lapisan teratas (Gambar 4.). Terdapat spike mulai kedalaman $3 \mathrm{~cm}$ ke atas, yang menunjukkan kenaikan drastis kandungan karbon dan karbonat pada lapisan teratas.

\section{Analisis Foraminifera}

Foraminifera diamati terdapat pada kedalaman 4 $-9 \mathrm{~cm}$ yang merupakan lapisan kandidat tsunami. Spesies yang diamati adalah Orbulina universa,
Rhabdamina discreta, Dentalina sp., dan Uberella $s p$.

\section{Analisis XRF}

Elemen kimia yang ada di Sampel SIM 3B yaitu $\mathrm{Zr}, \mathrm{Sr}, \mathrm{Rb}, \mathrm{Fe}, \mathrm{Ti}, \mathrm{Ca}$ dan K . Komposisi elemen kimia dalam sampel ini, pada elemen tersebut fluktuatif atau naik turun. Kadar elemen Fe dan Ti pada sampel cenderung naik dari lapisan paling bawah sampai atas (Gambar 5.).

\section{Analisis FTIR}

Pada sampel SIM 3B, hasil analisis FTIR menunjukkan pada kandidat tsunami cenderung memiliki gelombang inframerah yang mengindikasikan keterdapatan jenis mineral yang lebih banyak dibandingkan lapisan non kandidat (Tabel 1). Kandungan kuarsa ditemukan pada setiap lapisan. Kuarsa merupakan mineral yang resisten terhadap proses eksogenik termasuk oleh gelombang tsunami. 


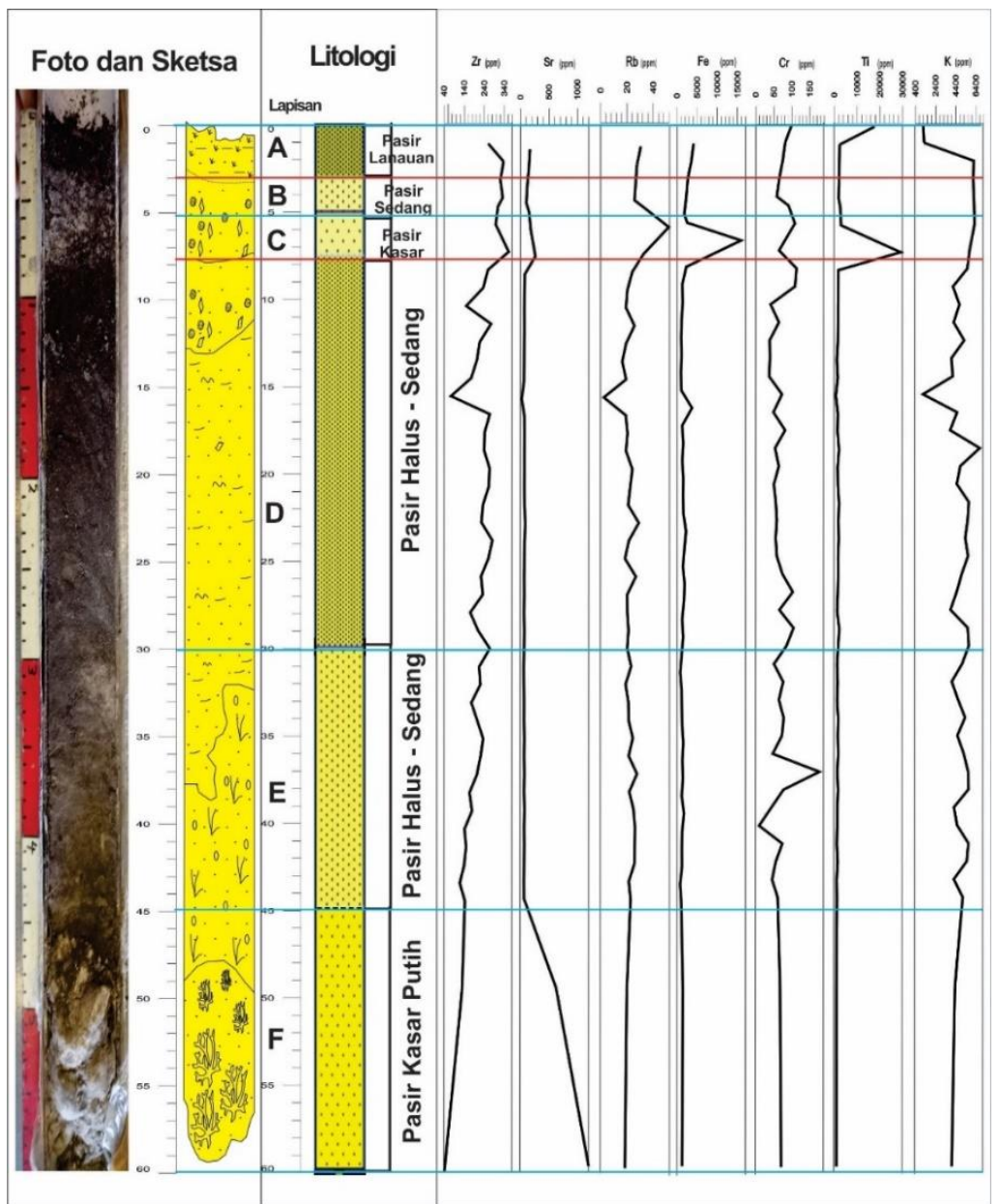

Gambar 5. Kenampakan sampel SIM 3B dengan parameter analisis XRF

Tabel 1. Hasil mineral SIM 3B yang ditemukan berdasarkan analisis FTIR

\begin{tabular}{cll}
\hline Ked $(\mathrm{cm})$ & \multicolumn{1}{c}{ Mineral yang ditemukan } & \multicolumn{1}{c}{ Lapisan } \\
\hline $0-2$ & kuarsa & Lapisan non kandidat tsunami \\
$3-4$ & kuarsa, kalsit & Lapisan kandidat tsunami \\
$5-6,5$ & kuarsa, feldspar, aragonite montmorilonit & Lapisan kandidat tsunami \\
$6,5-7,5$ & kuarsa, feldspar, ilit, montmorilonit, aragonit & Lapisan kandidat tsunami \\
$7,5-9$ & kuarsa, palygorskite, feldspar, aragonit, magnetit, & Lapisan kandidat tsunami \\
& biotit, montmorilonite & \\
$9-20$ & kuarsa, palygorskite & Lapisan non kandidat tsunami \\
$30-31$ & kuarsa, palygorskite, albit & Lapisan non kandidat tsunami \\
$45-50$ & kuarsa, palygorskite, albit & Lapisan non kandidat tsunami \\
$50-60$ & kuarsa, palygorskite & Lapisan non kandidat tsunami \\
\hline
\end{tabular}

\section{PEMBAHASAN}

\section{Mekanisme Pengendapan}

Kandidat tsunami dapat ditentukan melalui nilai mean, sortasi, skewness, kurtosis, kandungan organik, karbonat ataupun komposisi lainnya dengan melihat pola penurunan atau peningkatan secara tiba-tiba secara sesaat dan signifikan. Pada sampel SIM 3B, kandidat tsunami berada pada kisaran kedalaman 3-8 $\mathrm{cm}$ pada lapisan pasir halus lanauan sortasi buruk.

Karakteristik kandidat tsunami pada sampel penelitian ini yaitu ditunjukan dengan bentuk grafik diagram (phi) berupa bimodal yang berarti bahwa lapisan tersusun atas beberapa satuan ukuran butir, tingkat pemilahan termasuk dalam sortasi buruk dan ukuran butir yang termasuk dalam pasir sedang sampai pasir sangat halus. 
Pada grafik bivariate yang membandingkan dua parameter yang berbeda pada kandidat tsunami dengan lapisan lainnya menunjukkan bahwa lapisan tsunami cenderung berkelompok menjadi satu bagian (Gambar 6). Hal tersebut mengindikasikan bahwa berdasarkan analisis bivariate, lapisan kandidat memiliki karakteristik hampir sama.

Mekanisme pengendapan lapisan ini berdasarkan Passega (1964) termasuk ke dalam uniform suspension (Gambar 7). Hal tersebut dapat mengindikasikan bahwa ukuran butir yang diendapkan halus dengan energi pengendapan yang rendah. Lapisan kandidat atau lapisan A (pasir halus sortasi buruk) berdasarkan hasil plot menggunakan diagram Stewart (1958) menunjukkan adanya proses pengendapan river process (Gambar 8). Ketika adanya gelombang tsunami run up yang datang dari arah laut akan membawa material dari laut menuju ke darat. Mekanisme river process akan mengendapkan material yang berasal dari darat sebagai akibat gelombang tsunami.

Pada lapisan A, proses pengendapan menunjukkan river process yang berarti ketika endapan tsunami telah selesai diendapkan, di atasnya akan terendapkan lapisan darat yang lain yaitu lapisan B. Proses gelombang tsunami dalam satu kejadian hanya berupa satu kali gelombang run up, hal tersebut diindikasikan dari topografi dari daerah penelitian. Adanya topografi yang lebih tinggi yang menghalangi air laut kembali ke laut.

\section{Karakteristik Sedimentologi dan Geokimia Endapan Tsunami}

Komponen LoI pada lapisan ini cenderung mengalami kenaikan dibandingkan lapisan di bawahnya. Tingginya kandungan karbonat lapisan ini diindikasikan berasal dari pecahan cangkang. Adanya mikrofauna foraminifera pada lapisan sedimen ini menunjukkan bahwa terdapat material dari laut yang ikut terendapkan. Kandungan karbon yang rendah mengindikasikan kurangnya material organik yang dibawa dari darat.

Hasil analisis XRF lapisan ini menunjukkan pola anomali dibandingkan lapisan lainnya. Kandungan $\mathrm{Fe}$ dan $\mathrm{Ti}$ yang tinggi pada lapisan tsunami yaitu pasir halus lanauan sortasi buruk A. $\mathrm{Fe}$ dan $\mathrm{Ti}$ merupakan mineral berat yang merupakan indikator terestrial dan energi pengendapan tinggi (Font dkk., 2013). Nilai Sr dan $\mathrm{Zr}$ berbanding terbalik, $\mathrm{Sr}$ cenderung tinggi

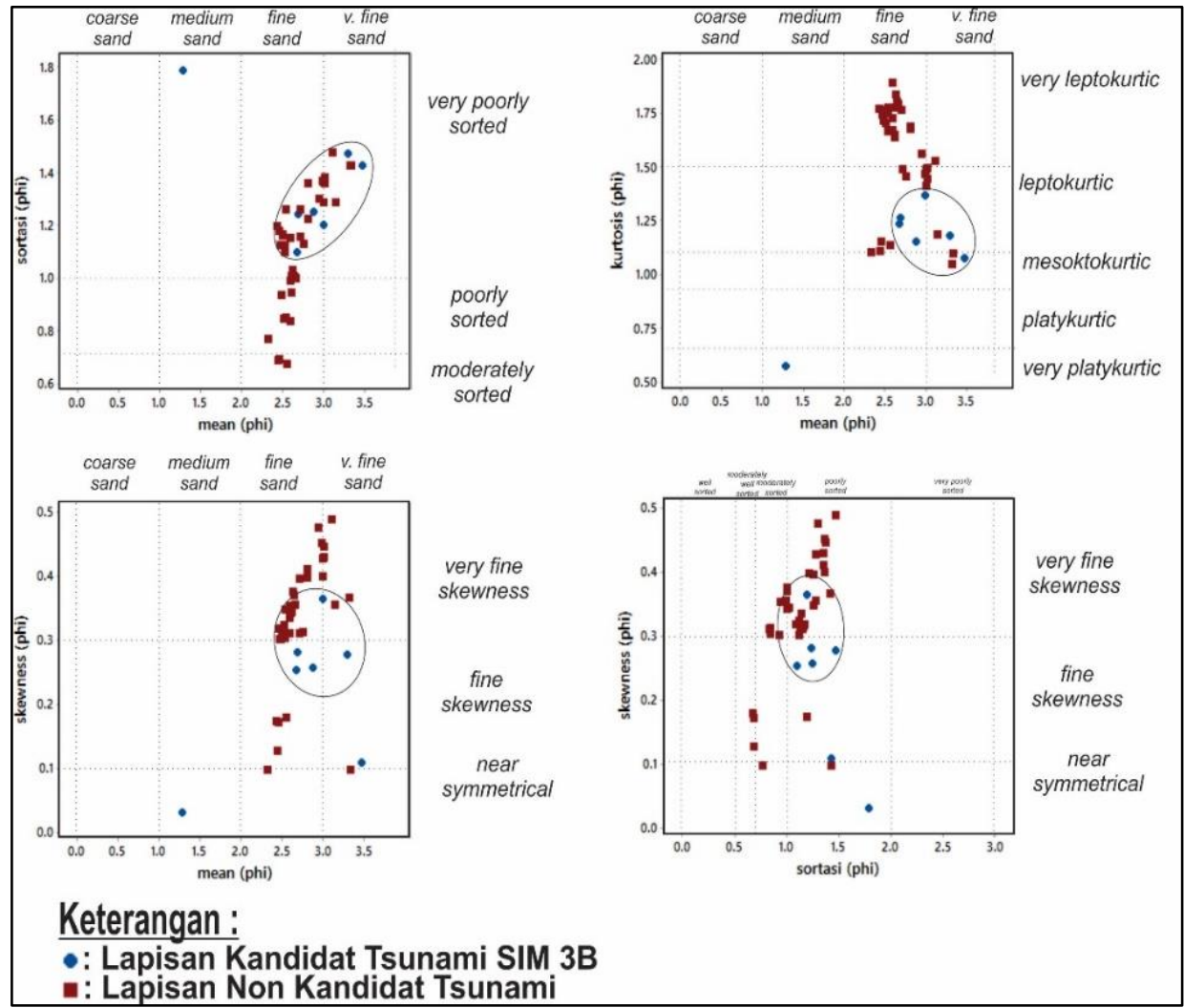

Gambar 6. Analisis bivariate SIM 3B dengan berbagai parameter 


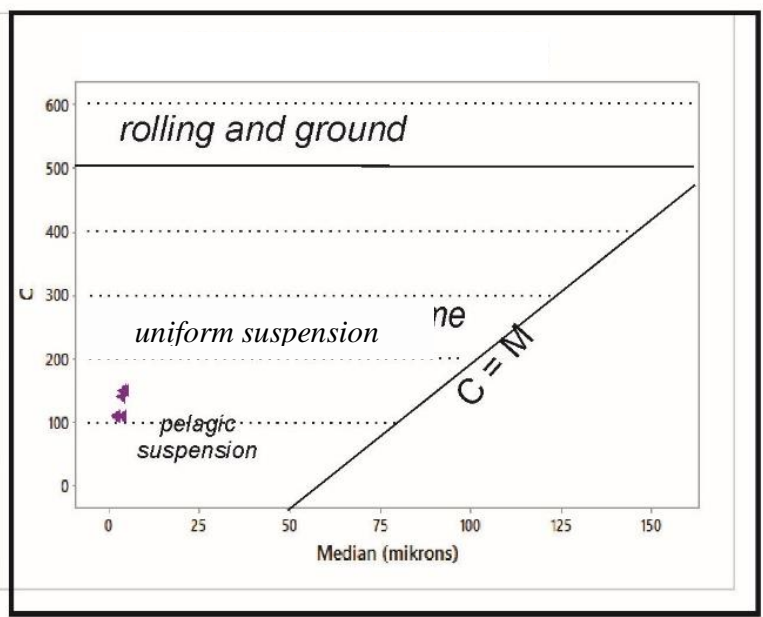

Gambar 7. Mekanisme pengendapan lapisan kandidat tsunami SIM 3B menurut Passega (1964)

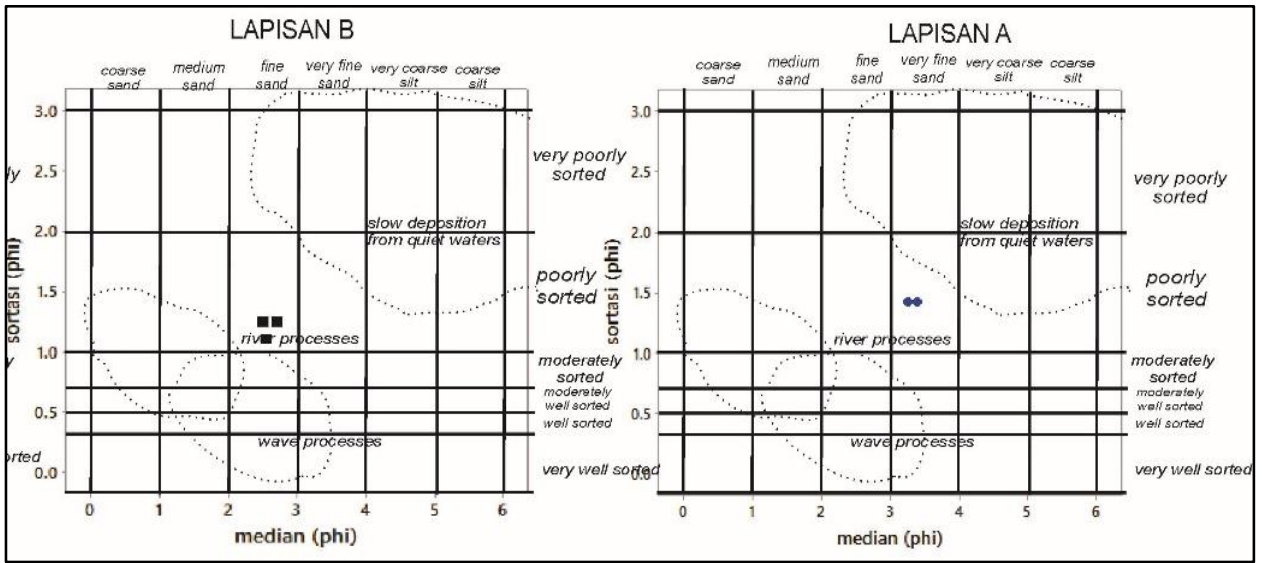

Gambar 8. Mekanisme pengendapan lapisan kandidat tsunami SIM 3B menurut Stewart (1958)

dan $\mathrm{Zr}$ rendah pada lapisan yang lebih dalam mengindikasikan bahwa lingkungan pengendapan laut (Chen dkk., 1997). Kandungan $\mathrm{Cr}$ yang cenderung konstan menunjukkan bahwa tidak ada pengaruh tingkat salinitas yang signifikan terhadap endapan tsunami ataupun non endapan tsunami (Wedepohl, 1995). Kandungan elemen jejak $\mathrm{Rb}$ pada lapisan tsunami sampel SIM 3B menunjukkan adanya pola yang berbeda dibandingkan lapisan di atas atau bawahnya, meski $\mathrm{Rb}$ tidak secara langsung menjadi indikator proses atau penciri endapan tsunami.

Secara mineralogi, endapan tsunami sampel SIM 3B menunjukkan jenis yang lebih beragam dilihat dari hasil analisis FTIR. Kuarsa adalah mineral paling melimpah dan memiliki resistensi yang tinggi, sehingga dapat ditemukan pada seluruh endapan baik asal laut maupun darat. Mineral oksida besi dan feldspar juga merupakan hasil rombakan material terestrial. Keterdapatan mineral lempung yaitu ilit, monmorilonit, dan paligorskit merupakan hasil ubahan dari mineral silikat yang dapat terbentuk baik di lingkungan laut maupun darat. Kalsit dan aragonit terbentuk di lingkungan laut hasil dari deposisi cangkang organisme. Keberagaman mineral asal darat dan laut ini hanya terdapat pada endapan tsunami pada kedalaman 3-9 cm.

\section{KESIMPULAN}

Berdasarkan analisis yang dilakukan, dapat disumpulkan bahwa pada daerah penelitian ditemukan endapan tsunami pada kedalaman 3-9 $\mathrm{cm}$. Kandidat endapan tsunami dapat dikenali secara megaskopis karena memiliki batas yang tegas. Material sedimen merupakan percampuran antara material asal darat berukuran pasir sedang - sangat halus. Distribusi ukuran butir adalah unimodal - bimodal dengan sortasi buruk. Analisis LoI menunjukkan komponen karbonat dan karbon yang tinggi dibanding lapisan di bawahnya, disebabkan adanya percampuran material asal darat dan laut pada saat tsunami. Keberadaan mikrofauna foraminifera juga 
menjadi bukti adanya pengaruh laut yang kuat pada lapisan endapan tsunami. Unsur kimia $\mathrm{Zr}$, $\mathrm{Sr}, \mathrm{Fe}, \mathrm{Ti}, \mathrm{K}, \mathrm{Cr}$, dan $\mathrm{Rb}$ menunjukkan anomali pada endapan tsunami, yaitu cenderung naik. $\mathrm{Zr}$, $\mathrm{Fe}$, Ti berasal dari mineral berat, sedangkan $\mathrm{Sr}$ merupakan indikator pengaruh laut pada endapan tsunami. Secara mineralogi, endapan tsunami juga menunjukkan kelimpahan dan keberagaman mineral yang tidak dimiliki endapan nontsunami. Pemahaman karakteristik endapan tsunami di daerah penelitian didukung dengan persebarannya menjadi referensi untuk mitigasi bencana di masa mendatang.

\section{UCAPAN TERIMA KASIH}

Penelitian ini terlaksana dengan kegiatan Ekspedisi Widya Nusantara 2017 yang diadakan oleh Pusat Penelitian Oseanografi Lembaga Ilmu Pengetahuan Indonesia. Terima kasih diucapkan kepada Dr. Udhi Eko Hernawan, S.Si., M.Sc. selaku koordinator kegiatan yang telah memfasilitasi penelitian.

\section{DAFTAR PUSTAKA}

Blott, S. J. dan Pye, 2001. Gradistat: A Grain Size Distribution and Statistics Package For Analysis of Uncosolidated Sediments, Earth Surface, Process, and Landforms. Vol.26, hal.21-72

Chagué-Goff, C., Andrew, A., Szczuciński,W., Goff, J., dan Nishimura,Y., 2012. Geochemical signatures up to the maximum inundation of the 2011 Tohoku-Oki tsunami - implications for the 869 AD Jogan and other paleotsunamis, Sedimentary Geology 282, hal. 65-77.

Chen, L.L., Carmichael, G.R., Hong, M.S., Ueda , H., Shim, S., Song, C.H., Kim, Y.P., Arimoto, R., Prospero J., Savoie D., Murano K., Park J.K., Lee H.G., dan Kang C., 1997. Influence of continental outflow events on the aerosol composition at Cheju Island, South Korea, Journal of Geophysical ResearchAtmospheres, 102 , hal. 28551-28574

Font, E., Veiga-Pires, C., Pozo M., Nave S., Costas S., Ruiz Muñoz F., Abad M., Simões N., Duarte dan Rodríguez-Vidal J., 2013. Benchmarks and sediment source(s) of the 1755 Lisbon tsunami deposit at Boca do Rio Estuary, Marine Geology 343, hal 1-14.
Goff, J., McFadgen B.G, dan Goff C., 2004. Sedimentary differences between the 2002 Eastern storm and the $15^{\text {th }}$-century Okoropunga tsunami, southeastern North Island, New Zealand, Marine Geology 204 (12), hal. 235-250.

Passega, R., 1964. Grain size repersentation by CM pattern as a geological tool. Journal of Sedimentary Petrology 34, hal. 830-847.

Stewart, H.B., 1958. Sedimentary reflection on depositional environment, in San Mignellagoon, Baju California, Mexico. AAPG Bull 42, hal. 2567- 2618.

Wedepohl, K. H., 1995. Geochim, Cosmochim, Acta, 59(7), hal. 1217-1232.

Whitlow, K.F., 2008. The 2004 and 1861 Tsunami deposits on Simeulue Island, Western Sumatra, Laporan Tesis, The Graduate Faculty Central Washington University. 